\title{
Palaeoclimatic Evidences from the Quaternary Coastal Deposits, Southwestern, Nigeria
}

\author{
Olugbenga A. Boboye ${ }^{1}$, Adewale Akinmosin ${ }^{2}$ \\ ${ }^{1}$ Department of Geology, University of Ibadan, Ibadan, Nigeria \\ ${ }^{2}$ Department of Geosciences, University of Lagos, Lagos, Nigeria \\ Email: boboyegbenga@yahoo.com,waleakinmosin2001@yahoo.com
}

How to cite this paper: Boboye, O.A. and Akinmosin, A. (2018) Palaeoclimatic Evidences from the Quaternary Coastal Deposits, Southwestern, Nigeria. Open Journal of Geology, 8, 585-605. https://doi.org/10.4236/ojg.2018.86034

Received: April 16, 2018

Accepted: June 16, 2018

Published: June 21, 2018

Copyright ( 92018 by authors and Scientific Research Publishing Inc. This work is licensed under the Creative Commons Attribution International License (CC BY 4.0).

http://creativecommons.org/licenses/by/4.0/

(c) (i) Open Access

\begin{abstract}
The studies on some samples retrieved from the coastal sediment deposit have been carried out. The palynological and geochemical indices were evaluated with the view of determining their chronology, palaeoclimatic conditions that prevailed during the time of their emplacement and also to re-asses the palaeoenvironment of the Lagos coastal deposit in Dahomey Basin. The identification of diagnostic species age entails the palynological analysis while the geochemical analysis determines the provenance of these Quaternary sediments. The occurrences of Laevigatosporites sp., Zonocostites ramonae, Acrostichum aureum in abundance along with few long ranging forms suggest that the vegetation development was under a humid climate and that the sediments were deposited during cooler and wetter conditions. The presence and high abundance of Crassoretitriletes vanraadshooveni, Zonocostites ramonae, Canthiumidites sp., Sapotaceoidaepollenites sp. and Pachydermitesdiederixi palynomorphs indicate an age range of late Pliocene (Gelasian) to early Pleistocene (Calabrian) (2.588 - 1.806 Ma). This age range is known to correspond to the $3.7-3.8$ depositional cycles of relative change of coastal On-lap. The geochemical appraisal showed that the ratios of organic carbon-nitrogen $(\mathrm{C} / \mathrm{N})$ indicate that the sediments were sourced from aquatic, protein-rich and cellulose-poor milieu. The wetter climatic period has enhanced algae productivity as a consequence of greater wash-in of soil nutrients, and these periods are recorded as increased rate of organic carbon mass accumulation. Conversely, the dominance of a mangrove habitat, $\mathrm{Zo}$ nocostites ramonae suggests a mangrove swamp environment which was the most prevalent environment of the Lagos lagoon in the Pleistocene.
\end{abstract}

\section{Keywords}

Quaternary, Palynological, Lagoon, Organic Matter, Dahomey, Pleistocene, Environment 


\section{Introduction}

The area of study is located within the Lagos lagoon and lies within latitudes $06^{\circ} 10^{\prime \prime} \mathrm{N}-06^{\circ} 40^{\prime \prime} \mathrm{N}$ and longitudes $03^{\circ} 10^{\prime \prime} \mathrm{E}-003^{\circ} 40^{\prime \prime} \mathrm{E}$ (Figure 1). It is bounded in the north by extensive land area comprising major population and industrial centers, also bounded to the south by highbrow business and residential areas. The depth of the lagoon ranges from $4 \mathrm{~m}$ (in most parts) to between $8 \mathrm{~m}$ and 13 $m$ in the deepest part.

In the Quaternary period, the most recent geologic interval represents the last 1.8 million years. Its most striking feature is that the earth had cold Polar Regions, which led to periodic development of continental glaciers. It is also

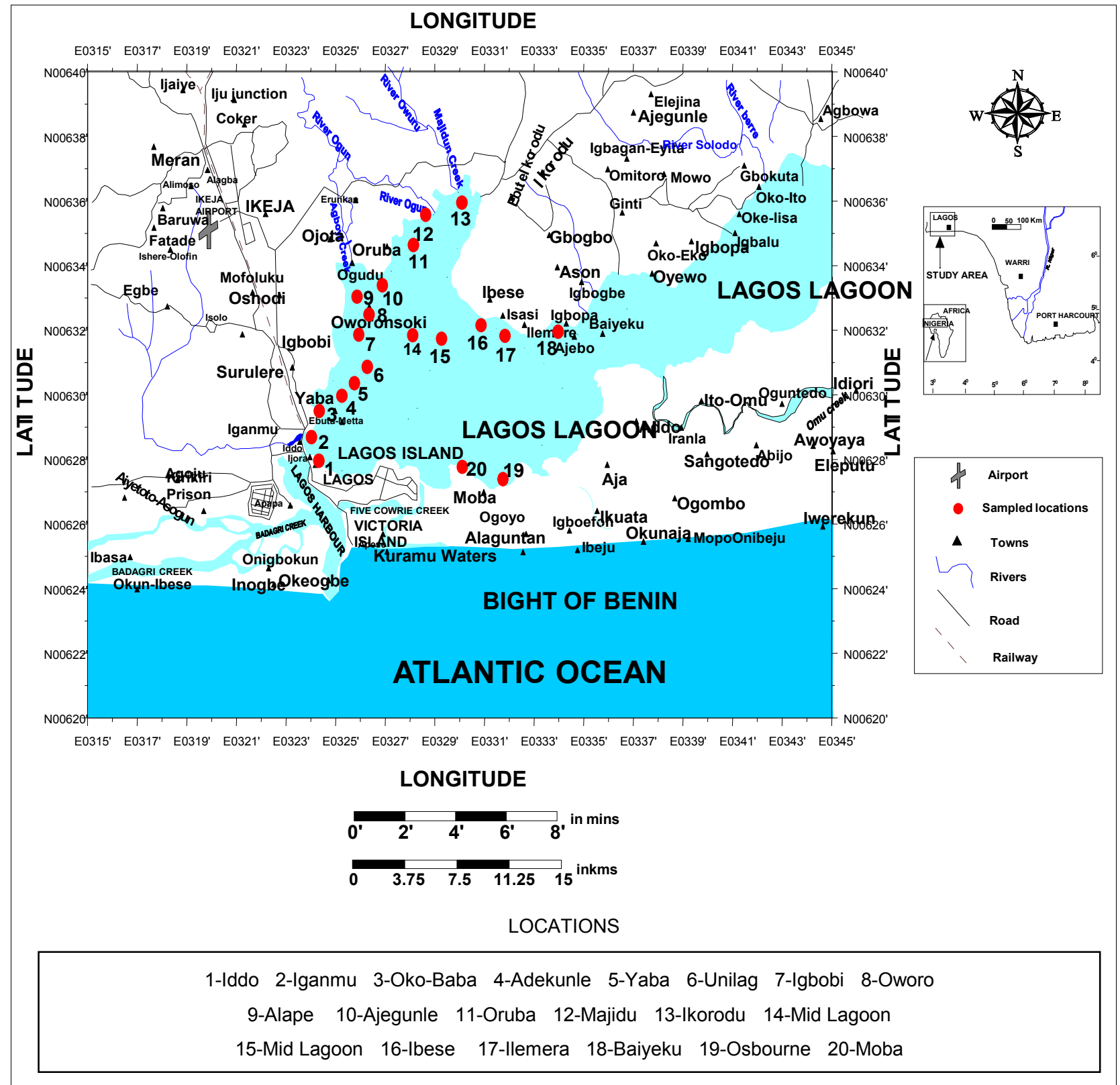

Figure 1. Location map of the study area showing the various sampling points. 
responsible for some important economic mineral deposits. The Quaternary period has been a time of environmental and climatic changes characterized by a sequence of approximately thirty glacial-interglacial cycles in the northern hemisphere [1]. This was a period of major environmental changes that were possibly greater than any other time in the last 60 million years. Nevertheless, there is no doubt that an understanding of climatic variation and changes during the Quaternary period is necessary not only to appreciate many features of the natural environment today, but also to comprehend fully our present climate [2]. The earth is right now entering a time of unusually warm climate. Significant and potentially rapid environmental changes could pose major challenges for human habitability.

One of the most pressing concerns for humans on earth today is climate change and what will happen in the future. Given that the climate is definitely warming, it is logical to ask two questions that have such changes happened before in the history of the earth and what will future climate holds? The expertise of Quaternary scientists is to interpret the changing world of the glacial ages and their impact on our planet's surface environments and understanding of the possible future climate change. The risk about global warming that we will face in coming years can be minimized through further climate based scientific research. Research on earth's climate in the recent geologic past provides insights into ways in which climate can change in the future. It also provides information that contributes to the testing and advancement of the computer models that are used to predict future climate change. Several excellent works on the basics of climate modelling are available [3] [4] [5] [6]. These models are the coupled general circulation models (GCMs) and are based on fundamental principles of physics and energy balance and the fluid flow of the earth's atmosphere and oceans. GCMs are designed to simulate earth's climate and test theories about climate change.

Climate research has expanded in tandem with a second component of the study of earth's climate: the extensive worldwide efforts to measure, observe, and monitor climatic variables using land and satellite-based methods. Global and regional atmospheric temperatures carbon budgets and sea level are just a few of the many types of data used by climatologists, atmospheric scientists, and oceanographers to examine secular trends and variability in climate [7] [8] [9] [10] [11]. A more complete synthesis of palaeoclimate is available through the integration of data from multiple proxies [12].

Pollen analysis plays a critical role in climate change studies during the Quaternary [13]. It is also the single most important branch of palaeoecology for the Pleistocene and Holocene [14]. A fundamental operating assumption is that the pollen-vegetation climate relationships that can be observed now also operated in the past [14]. Sediments organic matter provides a variety of elemental and molecular proxies to reconstruct past climates and ancient environments [15]. The organic matter content of sediment is the residue of past biota, the amount and types of organic matter present in sediments consequently reflect environ- 
mental conditions [16]. The proportions of sedimentary organic matter that originate from aquatic as opposed to terrestrial sources can be distinguished from compositional differences between algae and vascular land plants. The elevated $\mathrm{C} / \mathrm{N}$ ratios found in sediment records implies periods of enhanced aquatic palaeoproductivity [17]. Phytoplanktons usually have low $\mathrm{C} / \mathrm{N}$ ratios, of 4 and 10, while vascular land plants, that are cellulose-rich and protein-poor, have $\mathrm{C} / \mathrm{N}$ ratios of 20 and above [18]. However, for the first time in Nigeria, this study entails multi-proxies approaches to evaluate the palaeoclimate, palaeoenvironment, document the information achieved within the Lagos lagoon Quaternary sediments and to give credence to the present climatic conditions which are of prime importance to the changing earth that is influenced by man and natural activities.

\section{Physiographic Setting}

The study area is generally low-lying of about $12.0 \mathrm{~m}$ above sea level in all the Islands (Lagos, Victoria Island, Apapa and Ikoyi) and a little higher in its mainland extensions (north of the Lagos Lagoon). The topography is generally undulating and the pattern of relief in the Lagos area reflects the coastal location of the area. The hinterland is flat sometimes giving rise to swampy terrain.

The area lies within the sub-equatorial climatic region and it has distinct seasons; the dry season which starts in November and ends in March, as well as the rainy season which starts in April and ends in October. The Lagos area however is known to have a very unpredictable weather pattern with the possibility of rain during any time of the year. The mean annual rainfall is $1200 \mathrm{ml}$ per annum while the mean annual temperature is about $28^{\circ} \mathrm{C}$. The mean maximum temperature occurs in February and it is estimated to be $34^{\circ} \mathrm{C}$ while the mean minimum temperature of about $22^{\circ} \mathrm{C}$ has been recorded, particularly in August when there is dense cloud cover. A remarkable aspect of the climate due to its coastal location is the occurrence of land and sea breeze in which the cooling effect of the land breeze is more pronounced in the afternoon, while the sea breeze is more obvious at night.

The vegetation is typically rainforest, grading into mangrove type around the creeks surrounding the lagoons. Although, people seeking firewood and materials for the construction of fish traps as well as land developers have destroyed the mangrove in several areas.

The drainage pattern in the Lagos area reflects the coastal location of the area and forms part of a wider stretch of the coastal zone of southwestern, Nigeria (Figure 1). The Lagos lagoon areas serve as the convergence zone for a number of rivers. Each of these rivers such as Yewa, Ogun, Ona, Osun and Shahsa has developed prominent estuaries and flood plains into which other short streams drains (Figure 1). Two of these major rivers empty their contents into the Lagos lagoon. These are the fresh water bearing Ogun River and the brackish water laden Majidun River. 


\section{Previous Work}

About nine lagoons have been described in southwestern Nigeria [19] [20] [21] they are the Yewa, Badagry, Ologe, Iyagbe, Lagos, Kuramo, Epe, Lekki and Mahin Lagoons. The Lagos lagoon has received much attention because of its location in a commercial center. Considerable works have been carried out on the Quaternary deposits in Nigeria and some have involved their palynological and organic geochemical analyses. It has been studied by various authors including geologist, soil scientist, archaeologists, engineers and geomorphologists using different methods of research, the soil scientist have carried out extensive mapping and classification of soils over large parts of Nigeria [22] [23] [24] [25] [26].

Adekanmbi and Ogundipe worked on fourteen plant species belonging to four families of Acanthaceae, Amaranthaceae, Apocynaceae and Aracaceae from Lagos lagoon swamp and hinterland vegetation [27]. It was concluded that pollen belonging to the family Acanthaceae are mostly prolate in equatorial view and trigonal to circular in polar view. Family Amaranthaceae pollens are eurypalynous comprising of different morphological types of pollen, ranging from inaperturate to polyporate. Genera in the family Apocynaceae exhibit palynological extremes indicated by variety in the shape of the pollen grains, aperture, size and ornamentation of the studied species. Pollen grains in Aracaceae also exhibit variations ranging from monocolpate to trichotomosulcate nature of aperture. $\mathrm{Du}$ rugbo and other workers studied palynological evidence of Pliocene-Pleistocene climatic variations from the Western Niger Delta and opined that the dominance of Savanna pollen over wet climate indicators (mangrove, freshwater swamp species, brackish water swamp species and Palmae) and the preponderance of the dinocysts Polysphaeridium zoharyi and Operculodinium centrocarpum, species adapted to very saline and warm waters respectively, with abundant fungal spores dominated by Exesisporites sp., gives credence to a predominantly dry climate and lowered sea level during the Pliocene-Pleistocene (ca. 5.0 $1.3 \mathrm{Ma}$ ) in the Gulf of Guinea [28].

Adekanmbi and Ogundipe studied the relationship between pollen assemblage and vegetation in the Lagos lagoon [27]. They sampled eight lagoonal communities quantitatively with respect to their floral diversity and palynomorph content and recorded a total of ninety-six (96) palynomorph species. They observed that the palynofacies are made up basically of pollen grains sourced from local vegetation and only one regional plant and concluded that the palynomorph from Lagos Lagoon sediments truly represent the vegetation hence could be used to characterize parent vegetation communities.

Sowunmi studied terrestrial core from Ahanve in Badagry area of the coastal southwestern Nigeria [29]. The area was a Typha dominated freshwater swamp annually flooded by the Badagry Creek. The report stated that the dominant vegetation communities that prevailed in the coastal southwestern Nigeria was made up of abundant forests, Rhizophora dominated mangrove forest in the tidal zone, freshwater swamp forest in the swampy regions under freshwater influ- 
ence and drier, semi-deciduous forest on the well-drained areas with some woody, Savanna species and sparse grass cover at some intervals from ca. $8576 \pm$ $48 \mathrm{BP}$ to sometime prior to ca. $3109 \pm 26 \mathrm{BP}$.

Allen recorded that two series Quaternary sediments occur on the surface of the Nigeria continental shelf and slope overlying the Nigeria coastal plain geosynclines while working on the Nigeria continental margin, bottom sediment submarine morphology and geological evolution [30] (Figure 2). As it became evident that the Quaternary climate was marked by alternating wet and dry climatic phases, its effects on soil formation has been examined [31] [32]. Nwankwo reported that two factors, fresh water discharge from rivers and tidal seawater incursions influence the biological, physical and chemical characteristic of the Lagos Lagoon [33].

Salzman and other workers used the multiproxy approach to determine the late Quaternary climate and vegetation of the Sudanian zone of northern Nigeria [34]. They observed from pollen, diatoms and sedimentary geochemistry evaluations that dry climate conditions prevailed throughout the late Pleistocene. Nyer recognized the existence of distinct lithological horizons in the soil profiles in Ibadan [35], where a stratigraphic approach was applied to the study of superficial deposits in the area. This approach has been extended to some parts of the crystalline rock areas of southwestern Nigeria [36].

It is expected that within the large area of Nigeria and with a wide range of tropical climate belts, different sedimentation environments exist consequently different types of sediments have been deposited along the narrow Guinea Coast,

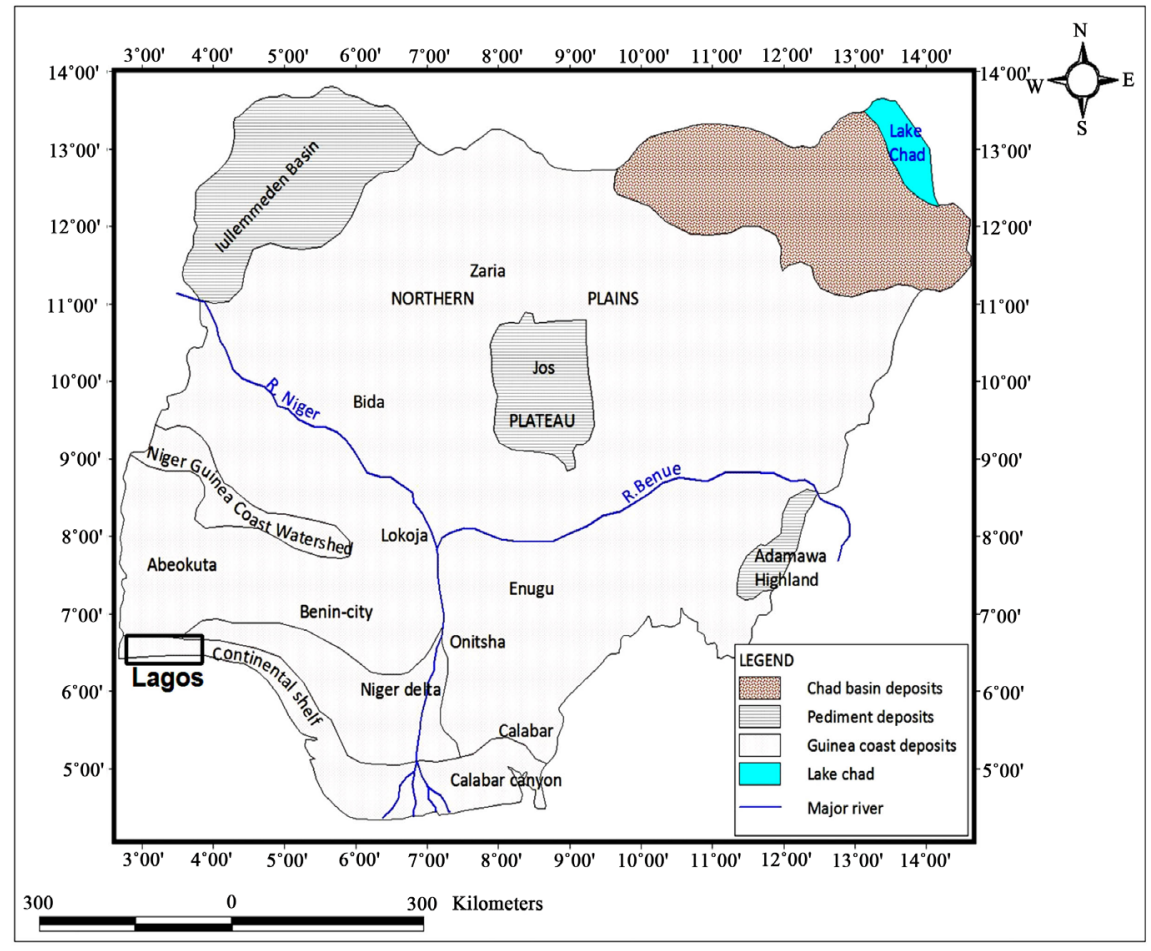

Figure 2. Map of quaternary deposits in Nigeria showing the study location (incised). 
sediments were deposited under the influence of fluctuating Quaternary, the behavior and sedimentation processes of especially the lower parts of the major rivers that flowed into the sea. Over the rest of the country, Quaternary sediments were laid down under the influences of alternating wet and dry climatic phases. This claim was also supported by Sowunmi on aspects of late Quaternary vegetation changes in West Africa [37] [38].

\section{Geological Setting}

The Lagos area falls within the Dahomey Embayment, an extensive sedimentary basin stretching from eastern Ghana, Togo and the Republic of Benin to the western part of Nigeria up to the Benin hinge line (Figure 3). The basin is one of the sedimentary basins in Nigeria; however, it is the eastern portion of the Dahomey Embayment that is exposed in the southwestern part of Nigeria. The eastern Dahomey Embayment is bounded in the north by the Precambrian Basement Complex of southwestern Nigeria, the Gulf of Guinea to the south and eastward by the Okitipupa ridge [39].

The Dahomey Embayment was initiated during the early Cretaceous as a result of separation of the Gondwanaland [40] [41] [42] [43] described the basin as pull-apart type- 5 basin, while Kingston and other workers described it as a marginal sag basin [44]. The Benin flank marks the zone of constriction in the basin and the thinning of the sediments and this separates the Dahomey Embayment from the Niger Delta Basin. Other work on tectonic structures includes that of Omatsola and Adegoke [45]. The sediments of the Dahomey Embayment are early Cretaceous to Holocene in age and are dominantly clastic with occurrence

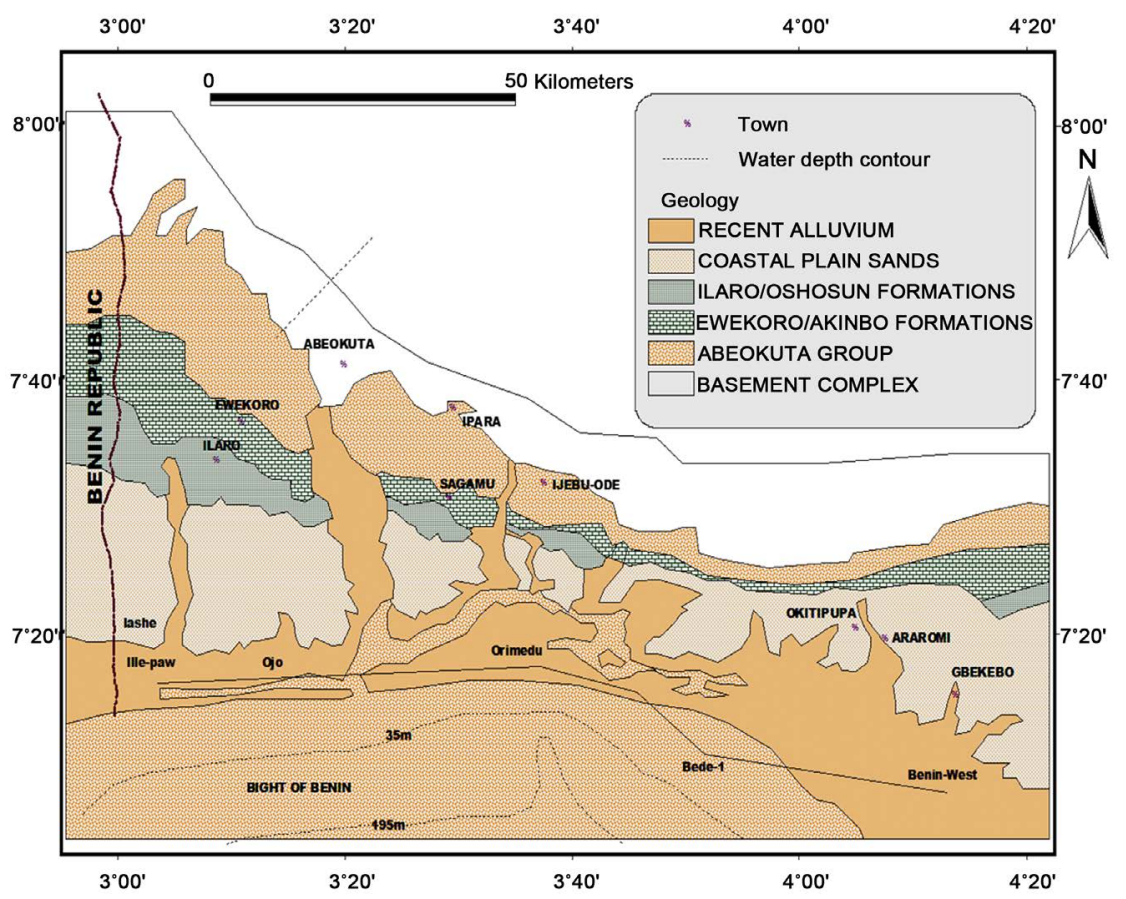

Figure 3. Geological map of the eastern Dahomey Embayment [46]. 
of shale and limestone [46]. The lithostratigraphy of the basin has been grouped: Abeokuta Formation which is the oldest formation in the basin [45] [47]. This group consists of conglomerate, sandstones, clays, shale and thin limestone. The Abeokuta Group is sub-divided into Ise, Afowo, and Araromi formations. The Ewekoro Formation is a lensoid shaped unit, which pinches out towards the east and south. The formation comprises limestone and marl that are fossiliferous particularly mollusks [46]. This formation has been subdivided into three units by Adegokeand other workers while Ogbe proposed a fourth unit of red phosphatic biomicrite (top), algal biosparite, shelly biomicrite and sandy biomicrosparite (bottom) [48] [49].

The Akinbo Formation overlies Ewekoro Formation of Palaeocene-Eocene age. It consists of well-laminated greenish grey and black shales. The base is defined by glauconitic rock bands in places [45]. The Oshosun Formation can be correlated to Ameki Formation which consists of grey mudstones in eastern Nigeria [50]. The Ilaro Formation overlies the Oshosun Formation which is predominantly made up of massive coarse, sandy estuarine deltaic and continental beds displaying rapid changes in facies. It consists of medium-fine grained sands yellowish in color with some clay fractions [47]. The formation is made up of both marine and continental massive yellowish consolidated sandstones. They are fine to medium grained, poorly sorted with some clay fractions. Ferruginous sandstones and ironstone bands indicate a hiatus in the depositional environment of the formation. It is assigned middle-upper Eocene based on the palynological studies. The formation is poor in microfauna but pollen and spores that are present indicate an Eocene age [39]. Jones described the Ilaro Formation as a lateral equivalent of the Oshosun Formation and estimated the thickness of $60 \mathrm{~m}$ [51].

The Coastal Plain Sands Formation is the youngest sedimentary unit in the eastern Dahomey Embayment, consisting of soft, very poorly sorted, clayey sands, sandy clay and rare thin lignite. The coastal plain sands are unfossiliferous except for plant remains. The thickness of the formation range from $10 \mathrm{~m}$ $100 \mathrm{~m}$ [52]. They are seen as the overburden that lacks fossil but contains plant debris which have been sources of dating [53]. This formation has been assigned Oligocene age.

\section{Sampling and Methodology}

This work involved the field study and laboratory analyses. The field exercise was carried out with the aid of sample Corer and motorised boat in the month of July, which lasted for two days due to the expansive nature of the lagoon and high water depth as a result of heavy downpour of late July. Systematic sampling covered the western part of the lagoon, Iddo, UNILAG, Oworo, Ikorodu, Agege and Ibese areas. These samples were taken by coring the basal floor of the lagoon, with the help of professional marine divers to depths ranging from $30 \mathrm{~cm}$ $1.0 \mathrm{~m}$ (Figure 4). This exercise was to collect samples for laboratory studies 


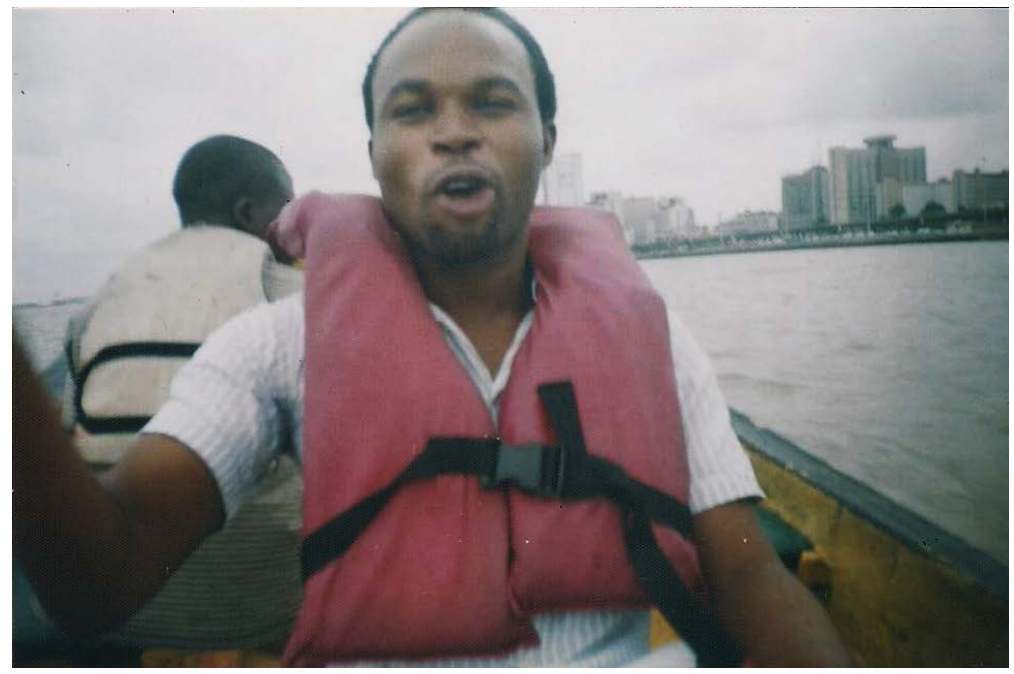

Figure 4. Fieldwork exercise on the Lagos lagoon.

while the exact locations and elevations of sampling points were made possible via the Global Positioning System (GPS) (Garmin Ventures HCx model). Samples were selected for palynological, organic geochemical (TOC) and elemental $(\mathrm{N})$ analyses.

\subsection{Palynological Analysis}

Total of twenty (20) samples of the Lagos Lagoon sediments were analysed for this study. $10 \mathrm{~g}$ of each sample were crushed to $3 \mathrm{~mm}$ size before the treatment with $10 \%$ hydrochloric acid $(\mathrm{HCl})$ to remove the carbonates that might be present in the samples. To ensure a complete removal of the carbonates, the hydrochloric acid $(\mathrm{HCl})$ was added in excess until no more effervescence was observed. After 24 hours, the acid was decanted and water added for another 24 hours for the first time and six hours for the second and third time. This is to ensure that the effect of the $\mathrm{HCl}$ is completely neutralized. The process was followed by the treatment of the samples with hydrofluoric acid (HF) for the removal of the silicates. Thirty five percent (35\%) HF was added and the whole set up were placed on a shaker for twenty four (24) hours. Thereafter, the content was allowed to settle for another twenty four (24) hours before the HF was carefully decanted. Neutralization with distilled water was repeated. To remove Fluorosilicate compounds which might be formed from the reaction of HF, the content were again treated with $\mathrm{HCl}$. Distilled water was again added to neutralise the effect of the acid. It should be noted here that no oxidation step was involved in this preparation as this process could selectively destroy the dinoflagellate present in the samples. The residues were then sieved using $10 \mu \mathrm{m}$ sieve for the recovery of the palynomorphs. The slides were carefully studied using a binocular microscope (LeitzDiaplan) for identification, counting and photographic documentation. The age determination is based on Evamy and other workers [53] and STRATCOM schemes. The results are presented in Table 1, Table 2, Table 3 and Table 4 and Figures 4-8. 


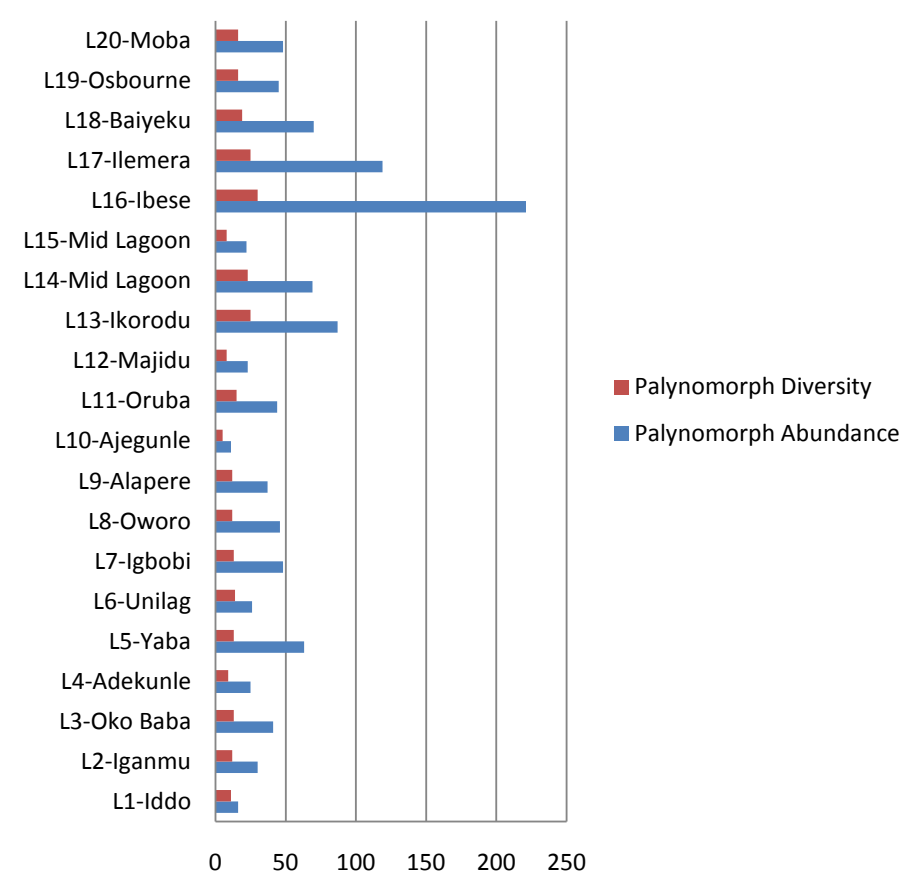

Figure 5. Palynomorphs abundance and diversity at diverse locations.

Table 1. Palynomorph abundance, diversity and their respective system tracts.

\begin{tabular}{|c|c|c|c|}
\hline Locations & Abundance & Diversity & System Tracts \\
\hline L1-IDDO & 16 & 11 & \multirow{20}{*}{$\begin{array}{c}\text { Transgressive } \\
\text { system } \\
\text { tract (TST) }\end{array}$} \\
\hline L2-IGANMU & 30 & 12 & \\
\hline L3-OKO BABA & 41 & 13 & \\
\hline L4-ADEKUNLE & 25 & 9 & \\
\hline L5-YABA & 63 & 13 & \\
\hline L6-UNILAG & 26 & 14 & \\
\hline L7-IGBOBI & 48 & 13 & \\
\hline L8-OWORO & 46 & 12 & \\
\hline L9-ALAPERE & 37 & 12 & \\
\hline L10-AJEGUNLE & 11 & 5 & \\
\hline L11-ORUBA & 44 & 15 & \\
\hline L12-MAJIDU & 23 & 8 & \\
\hline L13-IKORODU & 87 & 25 & \\
\hline L14-MID LAGOON & 22 & 8 & \\
\hline L15-MID LAGOON & 22 & 8 & \\
\hline L16-IBESE & 221 & 30 & \\
\hline L17-ILEMERA & 119 & 25 & \\
\hline L18-BAIYEKU & 70 & 19 & \\
\hline L19-OSBOURNE & 45 & 16 & \\
\hline L20-MOBA & 48 & 16 & \\
\hline
\end{tabular}



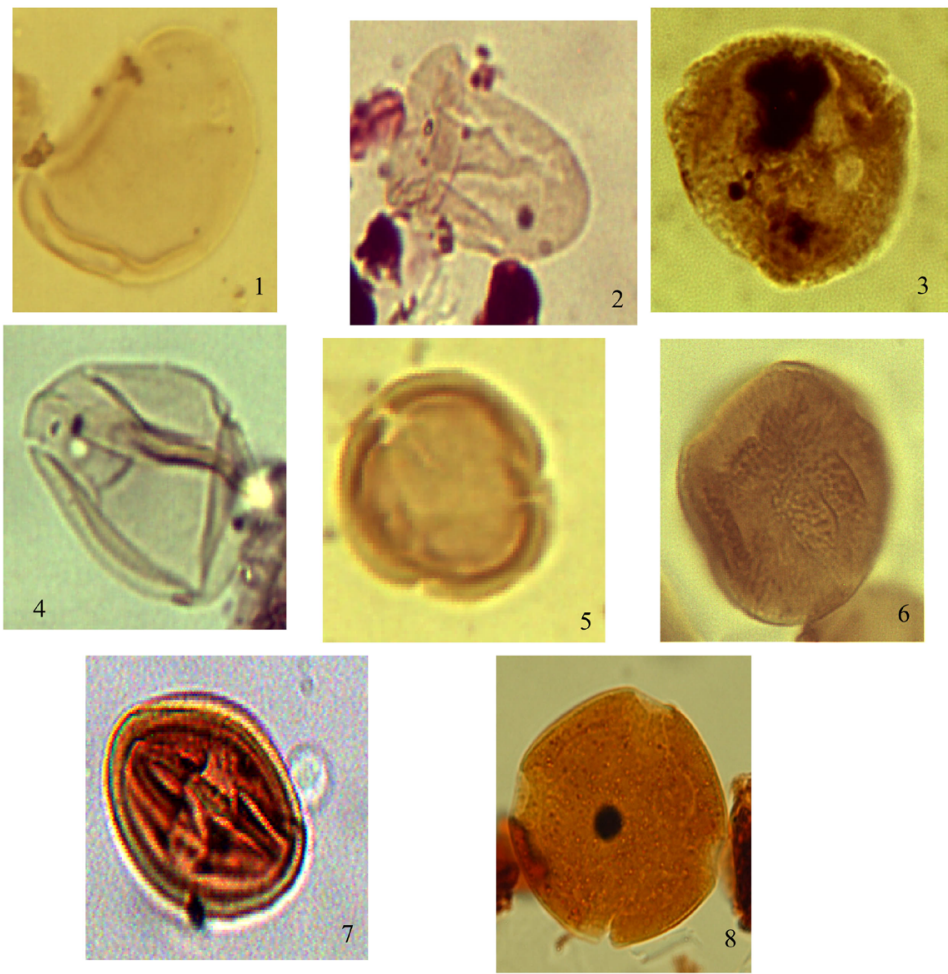

1. Laevigatosporites sp.; 2. Cyperaceaepollis sp.; 3. Retibrevitricolporites bodoensis;

4. Monoporites annulatus; 5. Zonocostites ramonae; 6. Retistephanocolpites gracillis;

7. Sapotaceoidaepollenites sp. and 8. Pachydermites diederixi

Figure 6. Photomicrographs of selected palynomorph taxa from the studied areas.
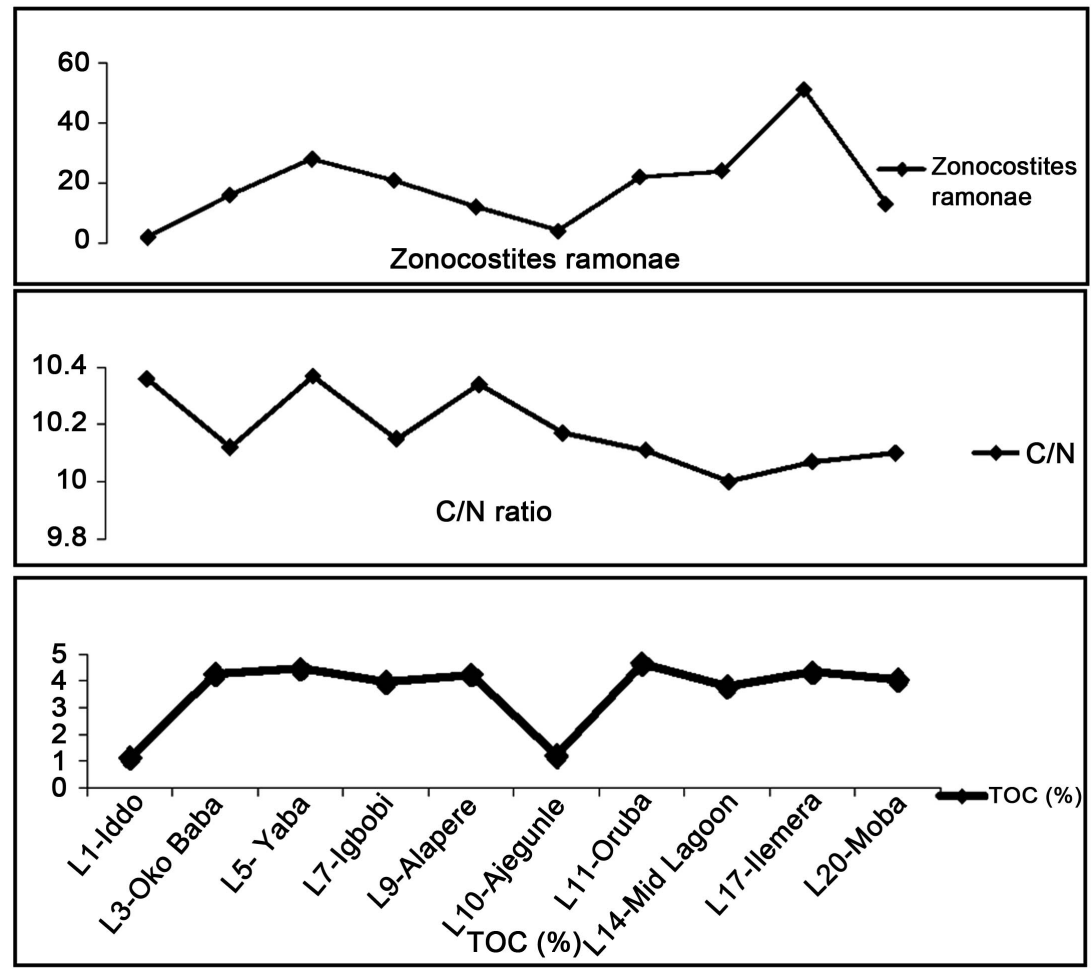

Figure 7. Organic carbon concentrations, atomic $\mathrm{C} / \mathrm{N}$ ratios, and the abundance of $Z o$ nocostites ramonae in sediments collected from different locations in the study area. 


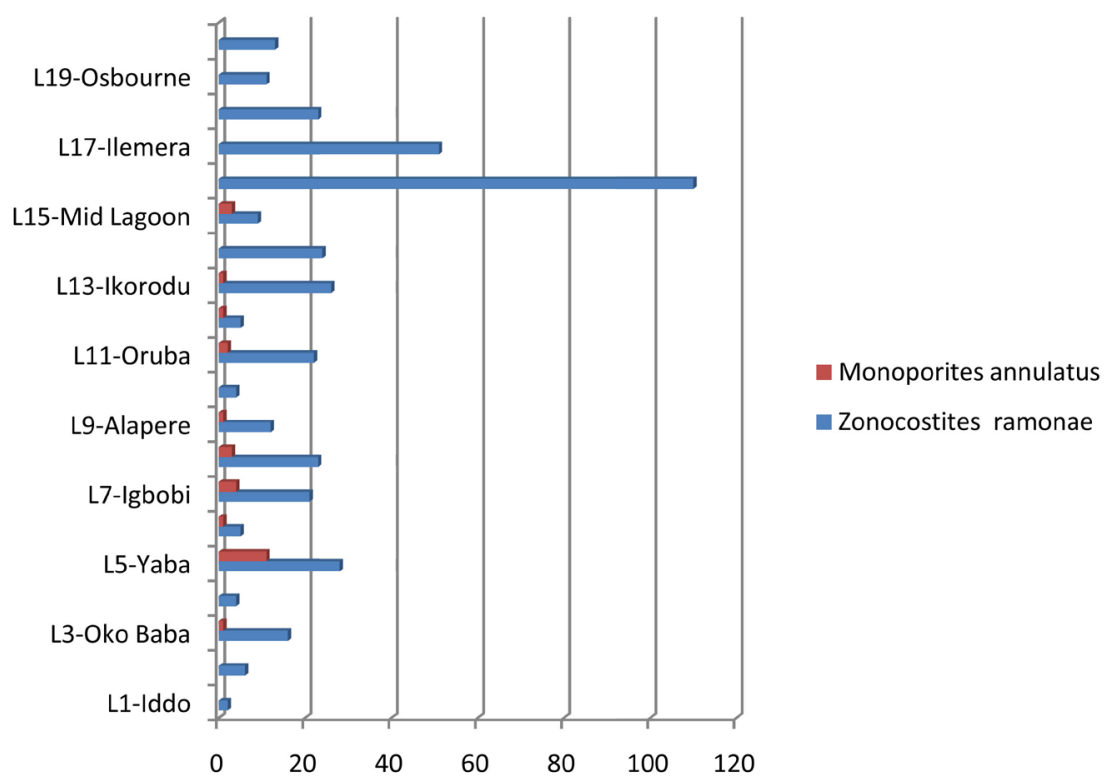

Figure 8. Distribution of Zonocostites ramonae and Monoporites annulatus in the study area.

Table 2. Abundance of diverse palynomorphs recovered from the study area.

\begin{tabular}{|c|c|c|c|c|c|}
\hline Locations & Zonocostites ramonae & Monoporites annulatus & Laevigatosporites sp. & Crassoretitriletes & $\begin{array}{c}\text { Sapotaceoidae } \\
\text { pollenites }\end{array}$ \\
\hline L1-IDDO & 2 & - & 2 & 1 & 3 \\
\hline L2-IGANMU & 6 & - & 4 & - & - \\
\hline L3-OKO BABA & 16 & 1 & 8 & 1 & 5 \\
\hline L4-ADEKUNLE & 4 & - & 4 & - & 2 \\
\hline L5-YABA & 28 & 11 & 11 & 4 & 8 \\
\hline L6-UNILAG & 5 & 1 & 5 & - & 2 \\
\hline L7-IGBOBI & 21 & 4 & - & - & 5 \\
\hline L8-OWORO & 23 & 3 & 8 & 4 & 2 \\
\hline L9-ALAPERE & 12 & 1 & 8 & - & 2 \\
\hline L10-AJEGUNLE & 4 & - & 3 & - & 1 \\
\hline L11-ORUBA & 22 & 2 & 5 & 3 & 2 \\
\hline L12-MAJIDU & 5 & 1 & 7 & 4 & - \\
\hline L13-IKORODU & 26 & 1 & 12 & 2 & 1 \\
\hline L14-MID-LAGOON & 24 & - & 14 & - & 1 \\
\hline L15-MID LAGOON & 9 & 3 & 3 & 4 & - \\
\hline L16-IBESE & 110 & - & 33 & 3 & 4 \\
\hline L17-ILEMERA & 51 & - & 27 & 1 & 3 \\
\hline L18-BAIYEKU & 23 & - & 10 & 2 & - \\
\hline L19-OSBOURNE & 11 & - & 9 & 1 & 1 \\
\hline L20-MOBA & 13 & - & 14 & 1 & - \\
\hline
\end{tabular}


Table 3. Palaeoclimatic conditions based on the recovered palynomorphs.

\begin{tabular}{lccc}
\hline \multicolumn{1}{c}{ Locations } & Zonocostites ramonae & Monoporites annulatus & Palaeoclimatic \\
\hline L1-Iddo & 2 & - \\
L2-Iganmu & 6 & - \\
L3-Oko Baba & 16 & 1 \\
L4-Adekunle & 4 & - \\
L5-Yaba & 28 & 11 \\
L6-UNILAG & 5 & 1 \\
L7-Igbobi & 21 & 4 \\
L8-Oworo & 23 & 3 \\
L9-Alapere & 12 & 1 \\
L10-Ajegunle & 4 & - \\
L11-Oruba & 22 & 2 \\
L12-Majidu & 5 & 1 \\
L13-Ikorodu & 26 & 1 \\
L14-MidLagoon & 24 & - \\
L15-MidLagoon & 9 & 3 \\
L16-Ibese & 110 & - \\
L17-Ilemera & 51 & - \\
L18-Baiyeku & 23 & - \\
L19-Osbourne & 11 & - \\
L20-Moba & 13 &
\end{tabular}

Table 4. Palaeoenvironment of the study area based on the recovered palynomorphs.

\begin{tabular}{|c|c|c|c|}
\hline Locations & Zonocostites ramonae & Monoporites annulatus & Environment \\
\hline L1-Iddo & 2 & - & \multirow{13}{*}{ Marginal Marine } \\
\hline L2-Iganmu & 6 & - & \\
\hline L3-Oko Baba & 16 & 1 & \\
\hline L4-Adekunle & 4 & - & \\
\hline L5-Yaba & 28 & 11 & \\
\hline L6-UNILAG & 5 & 1 & \\
\hline L7-Igbobi & 21 & 4 & \\
\hline L8-Oworo & 23 & 3 & \\
\hline L9-Alapere & 12 & 1 & \\
\hline L10-Ajegunle & 4 & - & \\
\hline L11-Oruba & 22 & 2 & \\
\hline L12-Majidu & 5 & 1 & \\
\hline L13-Ikorodu & 26 & 1 & \\
\hline L14-MidLagoon & 24 & - & \multirow{4}{*}{ Marginal Marine } \\
\hline L15-MidLagoon & 9 & 3 & \\
\hline L16-Ibese & 110 & - & \\
\hline L17-Ilemera & 51 & - & \\
\hline L18-Baiyeku & 23 & - & \multirow[t]{3}{*}{ Marginal Marine } \\
\hline L19-Osbourne & 11 & - & \\
\hline L20-Moba & 13 & - & \\
\hline
\end{tabular}




\subsection{Total Organic Carbon (TOC) Analysis}

A total of ten (10) samples (mudstone) were analysed for the total organic carbon (TOC) content. The samples were pulverized to pass through $0.5 \mathrm{~mm}$ mesh sieve before weighing. $250 \mathrm{mg}$ of the sample was weighed before it was transferred to a $250 \mathrm{ml}$ conical flask. Potassium Dichromate $\left(\mathrm{K}_{2} \mathrm{Cr}_{2} \mathrm{O}_{7}\right)$ was added by means of a $10 \mathrm{ml}$ pipette swirled for proper mixing. This was followed by the addition of $20 \mathrm{ml}$ of concentrated sulphuric acid $\left(\mathrm{H}_{2} \mathrm{SO}_{4}\right)$ into the mixture and was allowed to stand for 20 to 30 minutes. The suspension diluted with about $100 \mathrm{ml}$ of distilled water. $10 \mathrm{ml}$ of 1.10 phenantroline indicator was added. The excess dichromate $\left(\mathrm{Cr}_{2} \mathrm{O}_{7}\right)$ was back titrated with $0.5 \mathrm{~N}$ ferrous solution to green endpoint. The reagent was then run blank. It is imperative to run a blank titration so as to be able to measure the amount of reducing substances present in the reagent as impurities. The method described above is the Wackley-Black wet oxidation method [54].

$\% \operatorname{Org~C}=\left(\mathrm{meK}_{2} \mathrm{Cr}_{2} \mathrm{O}_{7}-\mathrm{meFeSO}_{4} \times 0.003 \times 100 \times \mathrm{f}\right) / \mathrm{g}$ of air-dry soil

Correction factor, $\mathrm{f}=1.33 ; \mathrm{Me}=$ Normality of solution $\times \mathrm{ml}$ of solution used;

$\%$ Org matter in sample $=\%$ Org Carbon $\times 1.729$. The results of the analyses are presented in Table 5 .

\subsection{Elemental Analysis}

For the total Nitrogen $(\mathrm{N})$ content, ten (10) samples were analysed which were pulverized and made passed through a $0.5 \mathrm{~mm}$ sieve before weighing $0.5 \mathrm{~g}$ that was transferred into $50 \mathrm{ml}$ digestion tubes. $2.5 \mathrm{ml}$ of sulphuric acid-selenium mixture was added into each tube then $6.25 \mathrm{~g}$ of selenium was dissolved into 1litre of concentrated sulphuric acid and the sample was mixed the acid on a vortex mixer. $2 \times 1 \mathrm{ml}$ of hydrogen peroxide $\left(\mathrm{H}_{2} \mathrm{O}_{2}\right)$ was added into each tube after which they were placed on a hotplate preheated to $300^{\circ} \mathrm{C}$. After 30 minutes of boiling, the condensing bottles were placed over each digest tube. The temperature was then increased to $320^{\circ} \mathrm{C}$ and left on the hotplate until the digest

Table 5. Geochemical results from the study area.

\begin{tabular}{ccccc}
\hline Locations & Sample ID & TOC $(\mathrm{wt} \%)$ & $\mathrm{N}(\%)$ & C/N Ratio \\
\hline Iddo & L1 & 1.14 & 0.11 & 10.36 \\
Oko baba & L3 & 4.25 & 0.42 & 10.12 \\
Yaba & L5 & 4.46 & 0.43 & 10.37 \\
Igbobi & L7 & 3.96 & 0.39 & 10.15 \\
Alapere & L9 & 4.24 & 0.41 & 10.34 \\
Ajegunle & L10 & 1.22 & 0.12 & 10.17 \\
Oruba & L11 & 4.65 & 0.46 & 10.11 \\
Mid lagoon & L14 & 3.80 & 0.38 & 10.00 \\
Ilemera & L17 & 4.33 & 0.43 & 10.07 \\
Moba & L20 & 4.04 & 0.40 & 10.10 \\
\hline
\end{tabular}


is clean, after which the samples were allowed to cool before diluting to $50 \mathrm{ml}$ with distilled water (Table 5 and Figure 7).

\section{Results and Discussion}

The twenty (20) samples processed for palynological study yielded a total of one thousand and forty-four (1044) palynomorphs of moderate to high abundance of pollen. Results show mainly dominance of Zonocostites ramonae (38\%), followed by Laevigatosporitessp. (16.7\%) while the abundance of Monoporites annulatusis about $2 \%$ of the total population (Table 1 and Table 2 and Figure 5 and Figure 6). Most of the samples with the exception of L1 and L4 consist mainly of Zonocostites ramonaeandLaevigasporitessp. They showmoderate to high palynomorphs abundance anddiversityrate that range from $30-221$ and 12 - 30 respectively suggesting marine deposition environment and/or very close to marine shoreline (Table 1, Figure 5). Samples L1 and L4 are low in palynoflora; however Zonocostites ramonae and Laevigatosporites sp. are common in these two samples. Samples L6, L10, L12, and L15 show low to moderate palynomorphs abundance and diversity which range from 11 - 43 and 5 - 18 respectively. The general trend of the abundance and diversity plots indicatea high palynomorphs abundance and diversity in the locations. This pattern is suggestive of high marine water level equivalent to a Transgressive Systems Tract (TST) (Table 1 and Figure 5). The use of palynomorph abundance and diversity in predicting eustatic sea level has been reported by Vail and Wornardt, hence suggesting the relative sea level position to be high [55] [56]. The total organic carbon (TOC) is to show an important component of palaeo environment evaluation in identifying the sources of organic matter in sediments and the carbon-nitrogen $(\mathrm{C} / \mathrm{N})$ ratios to identify the general origin of organic matter from aquatic and/or land plants [15]. The elemental analysis of the nitrogen $(\mathrm{N})$ in the samples and the different carbon-nitrogen $(\mathrm{C} / \mathrm{N})$ ratios show that the TOC range from $1.14 \mathrm{wt} \%$ to $4.65 \mathrm{wt} \%$ (Table 5 and Figure 7). Samples L1 and L10 recorded the lowest TOC values having $1.14 \mathrm{wt} \%$ and $1.22 \mathrm{wt} \%$. The $\mathrm{C} / \mathrm{N}$ ratio for all the samples is 10.00 to 10.37 indicating that they are from algal source and the high TOC values show they are deposited during a wet climate [18]. This corroborated with the palynological results that recorded a high abundance of Zonocostites ramonae which has been known as a wet climate indicator [57] [58] (Figure 7).

\section{Palaeoclimate and Palaeoenvironment}

The climatic condition of Lagos lagoonal area was determined by considering the total amount of mangrove pollen compared to the graminae pollen. However, the pollen (Zonocostites ramonae) was used against the grass type pollen (Monoporites annulatus) which is a known warm climate indicator [59] [60]. (Table 3). The total count of Zonocostites ramonae is generally higher than that of Monoporites annulatus in all locations suggesting a predominantly wet cli- 
mate for the sediments [16] [57] (Table 3 and Figure 8). The patterns of Zonocostites ramonae's frequency to Monoporites annulatus at diverse locations are different (Figure 8). According to Meyers the amount and types of organic matter present in sediments consequently reflect environmental conditions such as climate that impacted ecosystems at different past times [61]. Reliable source information can be derived in moderately preserved organic matter since algae which are protein-rich and cellulose-poor typically have atomic $\mathrm{C} / \mathrm{N}$ ratios of 4 10 , while vascular plants which are protein-poor and cellulose-rich (those composed in part of vascular tissue, including all flowering plants and the higher cryptogamous plants) have $\mathrm{C} / \mathrm{N}$ ratios greater than 20 [62]. Times of wetter climate result in enhanced algal productivity as a consequence of greater wash-in of soil nutrients, and these periods are recorded as lowered organic $\mathrm{C} / \mathrm{N}$ ratios and increased organic carbon mass accumulation rates [55]. The $\mathrm{C} / \mathrm{N}$ ratio values for each of the samples analyzed is 10 (Table 5). This is an indication that algal sources have dominated organic input to the sediments which means they are protein-rich and cellulose-poor. The TOC values are generally high, hence, the climate is suggested to be wet based on the values of $\mathrm{C} / \mathrm{N}$ ratios and the high organic carbon content as evident with the recovered palynomorph assemblages [63] [64] [65] (Table 5 and Figure 7). The major groups include pollen, spores, dinoflagellate and other associated forms which include foraminiferal wall linings. The high diversity and exclusive occurrence of land derived miosporesis an indication of fresh water condition. Schrank suggested that palynomorph assemblages with higher content of land derived miospores indicates terrestrial influence and vice versa [65].

However, the results show that mangrove pollen is generally higher than graminae pollen in all locations; this condition is suggestive of a marginal marine environment. The idea of marginal marine or shallow marine environments with low and fluctuating salinities is also supported by the low occurrence of dinoflagellates. Harland described the ratio of number of Gonyaulaceans to Peridiniods as a guide to palaeosalinity [66]. Nevertheless, the presence of non-pollen palynomorph (NPP); algae, fungi, charred graminae cuticle and foraminiferal wall linings; were considered along with them and some locations like L1, L2, L13 and L20 to have foraminiferal wall linings though the abundance of mangrove pollen is higher than the linings in these locations. The linings are probably organic remains of benthonic foraminifera which indicatenear shore shallow marine environment [67] [68].

Locations with fairly high amount of algae, fungi and charred graminae cuticle suggest the degree of the influence of fresh water inlet into the system, whereby high non-pollen palynomorphs show high influx of fresh water and vice-versa. Conversely, the presence of charred graminae cuticle suggest the proximity of the location to land and/or the degree of influx of wind and/or the amount of bush burning in the area as a result of anthropogenic factor. Ages are determined based on the presence and abundance of Zonocostites ramonae, Canthi- 
umidites sp., Crassoretitriletes vanraadshooveni, Sapotaceoidaepollenites sp., Pachydermitesdiederixi and some few long ranging forms. These forms largely occurred in the Gelasian (late Pliocene) and Calabrian (early Pleistocene).

\section{Conclusion}

The palaeoclimatic and palaeoenvironment evidences from the Quaternary deposits around Lagos lagoonal area have been established based on the recovered palynomorphs assemblages. The abundance of Zonocostites ramonae over Monoporites annulatusas well as other forms in the study area suggests a predominantly wet palaeoclimate in a marginal marine environment. However the absence of Podocarpus milanjianus and an age range of late Pliocene (Gelasian) to early Pleistocene (Calabrian) (2.588 - $1.806 \mathrm{Ma}$ ) corresponds to the $3.7-3.8$ depositional cycles of relative change of coastal On-lap. The palynological and organic geochemical indices revealed that the sediments were deposited during a wet climate and the $\mathrm{C} / \mathrm{N}$ ratio revealed that the source of the Lagos Lagoon organic matter is from algal productivity. The palynomorphs' assemblages further showed that the depositional environment is marginal marine and the age of the samples range from early Pleistocene to late Pliocene.

\section{References}

[1] Marshall, S.J. (2009) Glaciations, Quaternary. In: Gornitz, V., Ed., Encyclopedia of Paleoclimatology and Ancient Environments, Springer Science, Berlin, 389-393. https://doi.org/10.1007/978-1-4020-4411-3_97

[2] Bradley, R.S. (1999) Paleoclimatology: Reconstructing Climates of the Quaternary. 2nd Edition, Academic Press, San Diego, 1-10.

[3] McGuffie, K. and Henderson-Sellers, A., Eds. (1997) A Climate Modelling Primer. John Wiley and Sons Ltd., Chichester, New York, 288.

[4] Semtner, A.J. (1995) Modelling Ocean Circulation. Science, 269, 1379-1385. https://doi.org/10.1126/science.269.5229.1379

[5] Taylor, K.E. (1994) Climate Models for the Study of Paleoclimates. In: Duplessy, J.-C. and Spyridakis, M.-T., Eds., Long-Term Climatic Variations. Data and Modelling, Springer-Verlag, Berlin, 21-41. https://doi.org/10.1007/978-3-642-79066-9_2

[6] Trenberth, K.E. (1992) Climate System Modelling. Cambridge University Press, Cambridge.

[7] Jones, P.D. (1994) Hemispheric Surface Air Temperature Variations: A Reanalysis and an Update to 1993. Journal of Climate, 7, 1794-1802. https://doi.org/10.1175/1520-0442(1994)007<1794:HSATVA>2.0.CO;2

[8] Nicholls, N., Gruza, G.V., Jouzel, J., Karl, T.R., Ogallo, L.A. and Parker, D.E. (1996) Observed Climate Variability and Change. In: Houghton, J.T., MeiraFilho, L.G., Callender, B.A., Harris, N., Kattenberg, A. and Maskell, K., Eds., Climate Change 1995: The Science of Climate Change, Cambridge University Press, Cambridge, 137-192.

[9] Murray, J.W., Barber, R.T., Roman, M.R., Bacon, M.P. and Feeley, R.A. (1994) Physical and Biological Controls on Carbon Cycling in the Equatorial Pacific. Science, 266, 58-65. https://doi.org/10.1126/science.266.5182.58 
[10] Gornitz, V. (1995) Monitoring Sea Level Changes. Climate Change, 31, 515-544. https://doi.org/10.1007/BF01095160

[11] Gornitz, V. (1995) Sea-Level Rise: A Review of Recent Past and Near-Future Trends. Earth Surface Processes and Landforms, 20, 7-20. https://doi.org/10.1002/esp.3290200103

[12] Gornitz, V. (2009) Paleoclimate Proxies, an Introduction. In: Gornitz, V., Ed., Encyclopedia of Paleoclimatology and Ancient Environments, Springer Science, Netherlands, 716-721. https://doi.org/10.1007/978-1-4020-4411-3_171

[13] Faegri, K. and Iversen, J. (1975) Textbook of Pollen Analysis, 3rd Revised Edition, Hafner Press, New York, 295.

[14] Roberts, N. (1998) The Holocene: An Environmental History. 2nd Edition, Blackwell Publishers Ltd., Oxford, UK, 316.

[15] Meyers, P.A. (2009) Organic Geochemical Proxies. In: Gornitz, V., Ed., Encyclopedia of Paleoclimatology and Ancient Environments, Springer Science, Netherlands, 659-663. https://doi.org/10.1007/978-1-4020-4411-3_160

[16] Meyers, P.A. (1997) Organic Geochemical Proxies of Paleoceanographic, Paleolimnologic, and Paleoclimatic Processes. Organic Geochemistry, 27, 213-250. https://doi.org/10.1016/S0146-6380(97)00049-1

[17] Twichell, S.C., Meyers, P.A. and Diester-Haass, L. (2002) Significance of High C/N Ratios in Organic-Carbon-Rich Neogene Sediments under the Benguela Current Upwelling System. Organic Geochemistry, 33, 715-722. https://doi.org/10.1016/S0146-6380(02)00042-6

[18] Meyers, P.A. and Lallier-Vergès, E. (1999) Lacustrine Sedimentary Organic Matter Records of Late Quaternary Paleoclimates. Journal of Paleolimnology, 21, 345-372. https://doi.org/10.1023/A:1008073732192

[19] Kusemiju, K. (1988) Strategies for Effective Management of Water Hyacinth in the Creeks and Lagoons of South Western Nigeria. Proceedings of the International body on Water Hyacinth, Lagos, 7-12 August 1988, 39-45.

[20] Nwankwo, D.I. (2004) The Microalgae: Our Indispensable Allies in Aquatic Monitoring and Biodiversity Sustainability. University of Lagos Press, Lagos, 44.

[21] Onyema, I.C. and Nwankwo, D.I. (2009) Chlorophyll, a Dynamics and Environmental Factors in a Tropical Estuarine Lagoon. Academic Arena, 1, 18-30.

[22] Smith, A.J. and Montgomery, R.T. (1962) Soil and Land Use in Central Western Nigeria. The Government Press, Ibadan.

[23] Klinkenberg, K. and Higgins, G.M. (1970) An Outline of Northern Nigeria Soils. Samaru Research Bulletin, 107, 91-115.

[24] Deswardt, A.M.J. (1964) Laterization and Landscape Development in Parts of Equatorial Africa. Zeitschrift für Geomorphologie, 8, 313-333.

[25] Grove, A.T. and Warren, A. (1968) Quaternary Landforms and Climate on the South Side of the Sahara. Geology, 134, 194-208. https://doi.org/10.2307/1792436

[26] Boboye, O.A. and Nwosu, O.R. (2014) Petrography and Geochemical Indices of the Lagos Lagoon Coastal Sediments, Dahomey Basin (Southwestern Nigeria): Sea Level Change Implications. Quaternary International, 338, 14-27. https://doi.org/10.1016/j.quaint.2013.07.006

[27] Adekanmbi, O.H. and Ogundipe, O.T. (2009) Pollen Grains of Lagos Lagoon Swamp and Hinterland Vegetation-I. International Journal of Botany, 5, 270-278. 
https://doi.org/10.3923/ijb.2009.270.278

[28] Durugbo, E.U., Ogundipe, O.T. and Ulu, O.K. (2010) Palynological Evidence of Pliocene-Pleistocene Climatic Variations from the Western Niger Delta, Nigeria. International Journal of Botany, 6, 351-370. https://doi.org/10.3923/ijb.2010.351.370

[29] Sowunmi, M.A. (2004) Aspects of Nigerian Coastal Vegetation in the Holocene: Some Recent Insights. In: Battarbee, R.W., Gasse, F. and Stickley, C.E., Eds., Past Climate Variability through Europe and Africa, Battarbee Springer, Dordrecht, 258.

[30] Allen, J.R. (1964) The Nigerian Continental Margin: Bottom Sediments, Submarine Morphology and Geological Evolution. Marine Geology, 1, 298-332. https://doi.org/10.1016/0025-3227(64)90018-0

[31] Folster, H. (1968) Slope Development in South Western Nigeria during Late Pleistocene and Holocene. Gottinger Bodenkundliche Berchte, 10, 3-56.

[32] Folster, H., Moshrefi, N. and Ojanuga, A.G. (1971) Ferrallitic Pedogenesis on Metamorphic Rocks, SW Nigeria. Pedologie, 21, 95-124.

[33] Nwankwo, D.I. (1990) Distribution and Seasonal Variation of Dinoflagellates in Lagos Lagoon, Nigeria. Nigerian Journal of Botany, 3, 197-207.

[34] Salzmann, U., Hoelzmann, P. and Morczineck, I. (2001) Late Quaternary Climate and Vegetation of the Sudanian Zone of NE Nigeria. Quaternary Research, 58, 73-83. https://doi.org/10.1006/qres.2002.2356

[35] Nyer, P.H. (1954) Some Soils Forming Processes in the Humid Tropics. Journal of Soil Science, 5, 7-21. https://doi.org/10.1111/j.1365-2389.1954.tb02171.x

[36] Burke, K. (1970) An Outline of the Stratigraphy of Superficial Deposits of Ibadan. Institute of African Studies, University of Ibadan, Publications, 19, 45-55.

[37] Sowunmi, M.A. (1981) Late Quaternary Environmental Changes in Nigeria. Pollen Spores, 23, 125-148.

[38] Sowunmi, M.A. (1981) Aspects of Late Quaternary Vegetational Changes in West Africa. Journal of Biogeography, 8, 457-474. https://doi.org/10.2307/2844565

[39] Adegoke, O.S. (1969) Eocene Stratigraphy of Southern Nigeria. Bulletin Bureau de Research Geologique et Miners Memoirs, 69, 23-48.

[40] Burke, K. and Dewey, F.J. (1971) Orogeny in Africa. In: Dessauvagie, T.F.J. and Whiteman, A.J., Eds., African Geology, University of Ibadan Press, Nigeria, 583-608.

[41] Emery, K., Uchupi, O.E., Philips, J., Bowen, C. and Mascle, J. (1975) Continental Margin off West Africa: Angola to Sierra Leone. AAPG Bulletin, 59, 2209-2265.

[42] Whiteman, A.J. (1982) Nigeria: Its Petroleum Geology Resource and Potential. Graham \& Trotman, London. https://doi.org/10.1007/978-94-009-7361-9

[43] Klemme, H.D. (1975) Geothermal gradients, heat flow and Hydrocarbon Recovery. In: Fischer, A.G. and Judson, S., Eds., Petroleum and Global Tectonics, Princeton University Press, Princeton, 251-304. https://doi.org/10.1515/9781400885930-010

[44] Kingston, D.R., Dishroon, C.P. and Williams, P.A. (1983) Global Basin Classification System. AAPG Bulletin, 31, 87.

[45] Omatsola, M.E. and Adegoke, O.S. (1981) Tectonic and Cretaceous Stratigraphy of the Basin. Journal of Mining Geology, 54, 65-87.

[46] Agagu, O.A. (1985) A Geological Guide to Bituminous Sediments in South Western Nigeria. Unpublished Report, Department of Geology, University of Ibadan, Ibadan.

[47] Jones, H.A. and Hockey, R.D. (1964) The Geology of Parts of South Western Nige- 
ria. Geological Survey, Nigeria, Vol. 31, 101.

[48] Adegoke, O.S., Dessauvagie, T.F.J., Kogbe, C.A. and Ogbe, F.A. (1970) Type Section, Ewekoro Formation (Palaeocene) of Western Nigeria, Biostratigraphy and Microfacies. 4th African Micropalaeontology Colloquium, Abidjan, 37-39.

[49] Ogbe, F.G.A. (1970) Stratigraphy of Strata Exposed in the Ewekoro Quarry, Western Nigeria. In: Dessauvagie, T.F.J. and Whiteman, A.J., Eds., African Geology, University of Ibadan Press, Nigeria, 269-276.

[50] Ogbe, F.G.A. (1972) Stratigraphy of Strata Exposed in Ewekoro Quarry South Western Nigeria. In: Dessauvagie, T.F.J. and Whiteman, A.J., Eds., African Geology, University of Ibadan Press, Nigeria, 305-324.

[51] Jones, H.A. (1964) Phosphate Deposits in Abeokuta Province Rec. Geological Survey Nigeria, 7, 5-13.

[52] Reyment, R.A. (1965) Aspects of the Geology of Nigeria. University of Ibadan Press, Ibadan, 133.

[53] Evamy, D.D., Haremboure, J., Kamerling, P., Knaap, W.A., Molloy, F.A. and Rowlands, P.H. (1978) Hydrocarbon Habitat of Tertiary Niger Delta. AAPG Bulletin, 62, 1-39.

[54] Walkley, A. and Black, T.A. (1934) An Examination of the Titration for Determining Soil Organic Matter and a Proposed Modification of the Chromic Acid and Titration Methods. Soil Science, 37, 29-38.

https://doi.org/10.1097/00010694-193401000-00003

[55] Vail, P.R. and Wornardt, W. (1991) An Integrated Approach to Exploration and Development in the 90s: Well Log-Seismic Sequence Stratratigraphic Analysis. Gulf Coast Association of Geological Societies Transactions, 41, 630-650.

[56] Morley, R.M. and Richard, K. (1993) A Key Indicator of Late Cenozoic Climatic Change in the Niger Delta. Journal of Palaeobotany and Palynology, 77, 7-12.

[57] Leroy, S.A.G. and Dupont, L. (1994) Development of Vegetation and Continental Aridity in Northwestern Africa during the Late Pliocene: The Pollen Record of ODP Site 658. Paleogeography, Paleoclimatology, Paleoecology, 109, 295-316. https://doi.org/10.1016/0031-0182(94)90181-3

[58] Hooghiemstra, H., 1993. Paleoclimatic Conditions around 3 Million Years BP: Pollen Evidence from Colombia. University of Amsterdam, Amsterdam, 58.

[59] Hooghiemstra, H., Agwu, C.O.C. and Beug, H.J. (1986) Pollen and Spore Distribution in Recent Marine Sediments: A Record of NW-African Seasonal Wind Patterns and Vegetation Belts, Meteor Forschungsergebnisse, Deutsche Forschungsgemeinschaft, Reihe C Geologie und Geophysik, GebrüderBornträger, Berlin, Stuttgart, C40, 87-135. https://doi.org/10.1594/PANGAEA.549062

[60] Morley, R.M. (1995) Biostratigraphic Characterization of System Tracts in Tertiary Sedimentary Basins. Proceedings of the International Symposium on Sequence Stratigraphy in S.E. Asia, Jakarta, May 1995, 49-73.

[61] Boboye, O.A. and Egbeola, D. (2017) Sedimentological, Palynological and Stable Isotopes Studies on Quaternary to Neogene Sediments of the Eastern Dahomey Basin, Lagos, Southwestern, Nigeria. In: Balkema, Ed., The African Neogene, Climate, Environments and People, London, 61-86.

[62] Oloto, I.N. (1989) Maastrichtian Dinoflagellate Cyst Assemblage from the Nkporo Shale on the Benin Flank of the Niger Delta. Review of Paleobotany and Palynology, 57, 173-186.

[63] Van Bergen, P.F, Janssen, N.M.M., Alferink, M. and Kerp, J.H.F. (1990) Recognition 
of Organic Matter Types in Standard Palynological Slides. In: Fermont, W.J.J. and Weegink, J.W., Eds., International Symposium on Organic Petrology, Vol. 45, Mededelingen Rijks Geologische Dienst, 9-21.

[64] Ojo, O.J. and Akande, S.O. (2004) Palynological and Paleoenvironment Studies of the Gombe Formation, Gongola Basin, Nigeria. Journal of Mining and Geology, 40, 143-149.

[65] Schrank, E. (1984) Organic-Walled Microfossil and Sedimentary Facies in the Abu Tartur Phosphates (Late Cretaceous, Egypt). Berliner Geowissenchafliche Abhandlungen, 50, 135-150.

[66] Harland, R. (1978) Dinoflagellate Cysts and Acritarchs from the Bearpaw Formation (Upper Campanian) of Southern Alberta, Canada. Palaeontology, 16, 665-706.

[67] Gebhart, H. (1997) Cenomanian to Turonian Foraminifera, Ashaka (NE, Nigeria): Quantitative Analysis and Paleoenvironmental Interpretation. Cretaceous Research, 18, 17-36.

[68] Koutsoukos, E.A.M., Leary, P.N. and Hart, M.B. (1990) Latest Cenomanian Earliest Turonian Low Oxygen Tolerant Benthonic Foraminifera: A Case Study from Sergie Basin (NE Brazil) and Western Anglo Paris Basin (Southern England). Paleogeography, Paleoclimatology, Paleoecology, 77, 145-177.

https://doi.org/10.1016/0031-0182(90)90130-Y 